\title{
STRATEGIC BENEFITS, SYMBOLIC COMMITMENTS: HOW CANADIAN COLLEGES AND UNIVERSITIES FRAME INTERNATIONALIZATION
}

\author{
ELIZABETH BUCKNER \\ UNIVERSITY OF TORONTO
}

\author{
SCOTT CLERK \\ UNIVERSITY OF TORONTO
}

\author{
ADRIANA MARROQUIN \\ UNIVERSITY OF TORONTO
}

\author{
YOUZHANG \\ UNIVERSITY OF TORONTO
}

\begin{abstract}
This article examines how Canadian colleges and universities formally articulate their priority activities for internationalization, and what discursive rationales justify their approaches. Data come from 32 publicly-available internationalization strategies published in English by Canadian colleges and universities. In terms of practices, we find that institutions are adopting a largely similar set of activities, focused on partnerships and student and scholarly mobility. In terms of their justifications, we find that most institutions combine the strategic benefits of revenue generation and reputational prestige with symbolic commitments to diversity and excellence. We argue that by drawing on multiple rationales, internationalization strategies imbue the same generic activities with many meanings, which helps the internationalization project garner acceptance from an institution's diverse stakeholders. In concluding, we also point to a number of noticeably absent ideas, including equity, empathy, humility, and civic responsibility.
\end{abstract}

Keywords: internationalization, strategy, international students, research collaboration, student mobility, study abroad

\section{Résumé}

Cet article porte sur la manière dont les universités et les collèges canadiens articulent formellement et justifient leurs activités prioritaires en matière d'internationalisation. Les données proviennent de 32 stratégies d'internationalisation publiées en anglais par des universités et des collèges canadiens. Sur le plan des pratiques, nous observons que les établissements mettent en place des activités largement similaires qui se concentrent sur des partenariats et sur la mobilité des étudiants-es et des chercheurs-euses. En matière de justifications, nous observons que la majorité des établissements combinent les avantages stratégiques de la création de revenus et de prestige en proposant des engagements symboliques en faveur de la diversité et de l'excellence. Nous soutenons qu'en ayant recours à des motifs variés, les stratégies d'internationalisation proposent des significations multiples à des activités génériques, ce qui permet d'obtenir le soutien de divers intervenants institutionnels. En conclusion, nous relevons également l'absence de plusieurs concepts clés, notamment l'équité, l'empathie, l'humilité et la responsabilité civique.

Mots-clés : internationalisation, stratégie, étudiants internationaux, collaboration en recherche, mobilité étudiante, étude à l'étranger

\section{Introduction}

Colleges and universities throughout Canada increasingly recognize internationalization as a strategic priority (Chen, 2006; Khoo, 2011; Nerad, 2010). In fact, in 2014, $95 \%$ of universities included internationalization or global engagement as a priority in their strategic planning (Association of Universities and Colleges of Canada,
2014; the AUCC has since changed its name to Universities Canada). The prioritization of internationalization raises important questions about how international engagement is practiced and justified by higher education institutions that have historically oriented themselves to serving local and national communities (Buckner, 2017; Buckner, 2019; Enders, 2004).

The overriding assumption among institutional ad- 
ministrators and leaders is that internationalization will benefit the institution. It is framed as important for revenue generation, enhancing research productivity, and improving students' academic and labour market outcomes (Association of Canadian Community Colleges, 2010; Trilokekar, 2010). Despite a growing critical literature on internationalization in Canada (Beck, 2012; Stein, 2017; Stein \& de Andreotti, 2016), the literature remains largely oriented toward the experiences of international students and the impacts of outbound student mobility (see Chen, 2006; Garson, 2016; Guo \& Guo, 2017; Kenyon et al., 2012). We have surprisingly little empirical understanding of internationalization as an institutional practice-including what activities are included under the umbrella of internationalization and what values and ideas are used to justify priority activities (Grantham, 2018; Seeber et al., 2020). In this article, we draw on a set of internationalization strategies from 32 universities and colleges throughout Canada to examine how colleges and universities in Canada conceptualize and justify their internationalization practices.

We find that institutions are adopting a largely similar set of activities, focused on promoting international student and scholarly mobility, and developing partnerships overseas. In terms of their discursive justifications, a common tendency throughout the documents is to combine both strategic rationales of revenue generation and reputational prestige with symbolic commitments to diversity and quality. We argue that by drawing on multiple discourses, internationalization strategies imbue the same generic activities with many meanings, which likely helps internationalization garner acceptance from an institution's diverse stakeholders. Nonetheless, we also find that colleges and universities are tailoring priority activities and justifications to their particular geographic locations and institutional mandates. Localization makes institutional internationalization strategies more salient to diverse local contexts, yet rarely translates into truly distinctive approaches or priorities. In concluding, we point to a number of ideas that are noticeably absent in international strategies, including a near absence of values such as equity, empathy, humility, and solidarity.

\section{Conceptualizing the Benefits of Internationalization}

Internationalization is most commonly defined as a pro- cess of integrating international, intercultural, global, and cross-cultural perspectives into the purpose, functions, or delivery of post-secondary education (Knight, 2004). This broad conceptualization groups together a wide variety of organizational activities, including recruiting international students, supporting outbound mobility, promoting international research partnerships, and undertaking curricular reform (Buckner \& Stein, 2020).

These numerous activities are mapped onto wide-ranging goals and justified in terms of particular benefits for students, institutions, and nation-states (Altbach \& Knight, 2007). At the institutional level, internationalization is associated with revenue, rankings, and prestige, as well as research productivity and student learning (Seeber et al., 2016). Revenue generation is perhaps the most obvious operational benefit that internationalization offers institutions in Canada. International students accounted for $21 \%$ of all enrollments in Canada and added CAD $\$ 22$ billion to the Canadian economy in 2019 (El-Assal, 2020; Global Affairs Canada [GAC], 2019). The number of international students nearly tripled between 2000 and 2016, from 89,532 in 2000 to 245,895 in 2016 (Anderson, 2015; Statistics Canada, 2019a). This growth in students has been accompanied by "skyrocketing" tuition fees for international students brought about in part due to "ongoing budget cuts to public universities" (Anderson, 2015, p. 167). Despite some provincial variation, international students typically pay three to eight times higher tuition fees in Canadian universities, and recent data released by Statistics Canada show an increase of $33 \%$ in international undergraduate tuition at Canadian universities between 2015 and 2019 (Statistics Canada, 2019b).

In addition to revenue, internationalization supports universities' reputational goals, in what Khoo (2011) has called the "reputational arms race" (p. 344). Universities in Canada, like their peers around the world, have been affected by the development and proliferation of rankings that identify world-class universities, with metrics focused primarily on research excellence (Marginson \& van der Wende, 2007; Pusser \& Marginson, 2013). Institutions around the world increasingly link their internationalization activity to their position within a competitive landscape of higher education institutions. In analyzing approaches to internationalization at the University of British Columbia (UBC) and the University of Alberta, Khoo (2011) notes that UBC explicitly emphasized its "reputation," stating that its goal was to become 
the "best university" in Canada and one of the best in the world (p. 341), although these goals were not explicitly linked to global rankings. Similarly, in an analysis of how 33 Canadian universities discuss international student mobility in their university strategic plans, Grantham (2018) argues that international student mobility is overwhelmingly discussed in instrumentalist terms, stating: "in the sense that they are near-exclusively designed to promote the university" (p. 2).

Government policies also highlight the national interest in supporting internationalization-namely, the role that colleges and universities play as part of the immigration pathway. International students are characterized as precisely the skilled professionals that Canada is seeking to attract (GAC, 2019). In its most recent strategy, entitled Building on Success: International Education Strategy 2019-2024, Global Affairs Canada (2019) links international education to national human capital, stating that "international education can help Canada meet current and emerging labour-market challenges," while noting that Canada faces human capital shortages in technological industries and other skilled professions (p. 5).

While not discounting its strategic benefits, scholars drawing on the neo-institutional perspective in the field of higher education and comparative education have also explored how internationalization is a result of broader cultural and normative changes affecting higher education. They argue that internationalization is part of an abstracted normative model associated with excellence that confers both organizational legitimacy and distinction to universities (Buckner, 2019; Stensaker et al., 2019; Waldow, 2018).

One of the most powerful legitimating discourses for internationalization is that it will contribute to increased intercultural understanding, global awareness, and global citizenship broadly defined. In analyzing survey data from the Fourth Global Survey on Internationalization, Buckner (2019) found that the most common benefit associated with internationalization in the United States and English-speaking Canada was improving students' international awareness. In fact, despite what we know about the significant revenues international students bring, $86 \%$ of respondents in North America stated that one of the top three benefits of internationalization on their campus was "increased international awareness of/deeper engagement with global issues by students" compared to only $31 \%$ who stated that "revenue generation" was one of the top three benefits (p. 325).
These findings are in line with prior qualitative work examining how internationalization is framed in Canadian universities. In analyzing how the University of British Columbia (UBC) and the University of Alberta approach internationalization, Khoo (2011) argues that increasing global awareness has long been a central pillar of both universities' approaches to internationalization. For example, abstract commitments to global citizenship are made explicit in UBC's strategic plan, which states that its long-standing goal is to be "a provincial university' without provincialism" (p. 341). Both UBC and the University of Alberta make clear commitments to preparing students to be internationally aware global citizens. For example, UBC leaders publicly declared their intention to prepare "students to become exceptional global citizens" (p. 341), while Alberta lists its core values as "global citizenship," "global mindedness," "open-mindedness," and "appreciation of difference and diversity" (p. 343).

In a number of recent publications, Stein (2015, 2019) and Stein et al. (2019) help make sense of these various discourses for internationalization by mapping them onto what Stein et al. (2019) call different "orientating assumptions" (p. 25). These publications identify distinctive frames that shape how the purposes and goals of internationalization are understood: neo-liberal, liberal humanist, and anti-oppressive. A neo-liberal position articulates the benefits of global engagement in economic terms that allows individuals and institutions to "better compete in a global economy for their own benefit" (Stein, 2015, p. 243). Meanwhile, a liberal humanist position promotes mutual understanding based on a belief in universal humanity (Stein, 2015, p. 243). These two frames map closely onto what we have identified as strategic rationales, which promote individual economic benefits based on zero-sum competition, and symbolic rationales, which are based in normative commitments, including human rights and equality. Stein $(2015,2019)$ also identifies a third discursive frame, the anti-oppressive position, which calls for "critical, politicized, and historicized approaches to global engagement" (2015, p. 243). We draw on Stein's cartographies to classify the discourses and rationales employed by institutions in their strategy documents, as discussed below.

\section{Conceptual Framework}

We conceptualize internationalization as a rationalized organizational activity. Scholars have called internation- 
alization an intentional process (de Wit et al., 2015) and noted that it is achieved through "strategic planning efforts" (Schoorinan, 1999, p. 152). Our analysis focuses on internationalization strategy documents, which are discursive artifacts that articulate an institution's official approach to internationalization. Internationalization strategies are typically public-facing documents, produced by key actors in colleges and universities and formally endorsed by the highest levels of leadership (Childress, 2009; Taylor, 2004). They are also strategic documents that guide action by determining priority activities and resource allocation.

Developing an internationalization strategy involves consultations, negotiations, and decisions about what to include and how to frame these choices (Soliman et al., 2018). Drawing on a neo-institutional theory in sociology, which views organizations as embedded in and affected by their larger environment, we view the development of an institutional internationalization strategy as affected by broader norms within the profession. For the most part, the higher education administrators producing these strategy documents are aware of broader discussions concerning what, why, and how to internationalize occurring at colleges and universities around the world. They are often engaged in professional and practitioner communities and discussions with their peers at other institutions. In Canada, the Canadian Bureau of International Education (CBIE) has played an important role in advancing the professionalization of internationalization, through conferences and publications.

The literature suggests that new organizational practices are often mapped onto broader legitimating discourses that resonate with powerful stakeholders as a way of garnering acceptance. We draw on Stein's (2015, 2019) cartographies to identify dominant discourses and rationales for internationalization that are available to stakeholders. Strategic benefits map onto neo-liberal discourses and are framed as offering concrete economic or reputational benefits to the institution. Symbolic discourses are those rooted in the liberal humanist tradition and are often considered worthwhile even if they do not confer specific economic benefits or competitive advantages. Finally, anti-oppressive discourses highlight the role internationalization can play in disrupting existing power relations and may be linked to the university's role as a space for critique or tied to a decolonial mission. We expect that strategy documents will reflect many of these discourses. Table 1 presents an overview of rep- resentative codes from each of the three frameworks for selected priority activities. The table does not intend to be exhaustive; rather, it seeks to clarify how the research team classified discourses onto broader frameworks.

Throughout the process of designing an internationalization strategy, decision makers must interpret and edit the abstracted model of what internationalization is to the needs and priorities of their context. In some cases, internationalization may be viewed as competing with other priorities; therefore, stakeholders supportive of internationalization will frame it in particular ways that are likely to garner acceptance. Scholars have found that this often occurs by tailoring or localizing how a practice is discussed to ensure it resonates to powerful constituencies (Boxenbaum, 2006). Some strategies for doing this including portraying a particular practice as a solution to a local problem or aligning the practice to other long-standing goals of the institution (Sahlin \& Wedlin, 2008). For example, we expect many institutions will frame internationalization as a solution to issues such as declining revenue or as a way of better fulfilling their particular mandate. In our analysis, we examine how dominant justifications and priority activities in strategy documents vary across institutional type (i.e., college vs. university) and geographic location to see how strategy documents are being localized.

\section{Data and Methods}

Our data come from a sample of internationalization strategies produced by Canadian colleges and universities that were publicly available in English in 2019. For institutions with more than one strategy, we include only the most recent strategies. The sample includes 32 documents (i.e., strategies, plans, and white papers) published between 2012 and 2019 from nine colleges and 23 universities (see Appendix). While there are structural, governance, and mission differences between universities and colleges in Canada, the traditional line between institutional types continues to blur, as colleges further adopt the granting of bachelor degrees and the pursuit of research activities, while universities further align to career preparation (Clark et al., 2009). The fact that both colleges and universities publish these specialized strategies underscores the growing similarities between institutional types and warrants their comparison.

Using emergent, iterative qualitative coding (Charmaz, 2006), a team of research assistants coded key 
Table 1

Frameworks for Internationalization and Sample Representative Codes

\begin{tabular}{llll}
\hline \multicolumn{1}{c}{ Priority Activity } & \multicolumn{1}{c}{ Strategic } & \multicolumn{1}{c}{ Symbolic } & \multicolumn{1}{c}{ Anti-Oppressive } \\
\hline International Students & $\begin{array}{l}\text { Revenue; economic } \\
\text { benefits }\end{array}$ & $\begin{array}{l}\text { Cross-cultural understand- } \\
\text { ing; appreciating diversity }\end{array}$ & $\begin{array}{l}\text { In/equity; extractive tuition } \\
\text { fees; interpersonal and } \\
\text { institutional racism }\end{array}$ \\
Study Abroad & $\begin{array}{l}\text { Skills for global labor } \\
\text { markets }\end{array}$ & $\begin{array}{l}\text { Personal transformation; } \\
\text { global citizenship; global } \\
\text { awareness }\end{array}$ & $\begin{array}{l}\text { Humility; social justice; } \\
\text { solidarity; reciprocity }\end{array}$ \\
Research and Partner- & $\begin{array}{l}\text { Rankings; new sources of } \\
\text { funding }\end{array}$ & $\begin{array}{l}\text { Mutual benefits; knowl- } \\
\text { edge as a global public } \\
\text { good }\end{array}$ & $\begin{array}{l}\text { Unequal power relations; } \\
\text { colonial relationships; } \\
\text { decolonizing knowledge }\end{array}$ \\
\hline
\end{tabular}

activities and discourses in the documents. First, we documented the range of activities and initiatives mentioned in each strategy document. Our initial coding of a subset of documents resulted in a set of organizational practices, namely: recruiting international students, creating new programs or majors, founding new research partnerships, and supporting outbound mobility (i.e., study abroad), among others. We also identified major framing discourses including the knowledge economy, strategic positioning, global citizenship, revenue generation, international cooperation, and improving quality, among others.

Through this process, we refined a codebook that included a precise definition of each code, inclusion and exclusion criteria, and textual examples. Using Dedoose, a qualitative analysis software that is well suited to collaborative projects, we created a series of code-application tests to measure inter-rated reliability (Dedoose, 2018). All research team members completed the test, and we resolved any differences through discussion. The codebook was intended to be a dynamic document and we made changes as we moved forward. For instance, international development cooperation and Indigenous communities were two codes that emerged during coding.

Next, we conducted a quantitative content analysis to identify activities that were explicitly mentioned as priority activities in each strategy. We then examined variation in priority activities across four regions and institutional types. For the regional analysis, we grouped institutions into four regions: the Atlantic Region (four in- stitutions), Central Canada (15 institutions), the Prairie Provinces (six institutions), and the West Coast (seven institutions). To examine patterns across institutional type, we examined differences between colleges and universities. See Table 2 for an overview.

For the qualitative analysis, we also conducted targeted searches of key words to understand how common practices (e.g., recruiting international students) were discussed. As discussed above, we then classified specific discourses into overarching categories, namely strategic, symbolic, or anti-oppressive in order to identify which values and justifications were most common. As outlined in Table 1, strategic benefits include reputational prestige, including position on global rankings, and revenue. Symbolic commitments included commitments to diversity and quality, in line with broader commitments to educating for global citizenship and student learning. In addition, we noted the near absence of critical or anti-oppressive discourses, and so we carried out targeted searches of keywords, including "equity," "equality," and "humility," among other terms. In the sections that follow we report on findings from the quantitative content analysis and draw on representative quotes to discuss dominant framing discourses.

\section{A Generic Model}

An overarching finding from our quantitative content analysis was that Canadian colleges and universities have adopted a core set of activities or priorities for inclusion in their official international strategies or plans, 
with few distinctive approaches. This was confirmed in our regional analysis, where we found that priorities were largely similar across different regions. Three activities stood out as priorities for nearly all Canadian colleges and universities: supporting outbound student mobility, recruiting international students, and developing partnerships, with each appearing in more than $87 \%$ of strategies. However, certain priorities were clearly of greater importance to universities than colleges and vice versa; chief among these was support for research, with $87 \%$ of universities and $44 \%$ of colleges identifying research as a priority within their international strategies.

The most commonly identified priority across all Canadian strategies, appearing in $97 \%$ of these documents, was outbound student mobility. Institutional support for study abroad is nearly unanimous, and in line with sectoral priorities and Canadian federal government policy. Both of the national sectoral umbrella organizations for higher education, namely Colleges and Institutes Canada and Universities Canada, include outbound student mobility on their list of priorities for their advocacy work. The Canadian federal government included outbound student mobility as a priority in both its 2014 and 2019 International Education Strategies (Foreign Affairs, Trade and Development Canada, 2014; GAC, 2019). Interestingly, many studies consider study abroad as an area of weakness for Canada, citing comparatively low rates of study abroad by Canadian students (CBIE, 2016).

The other most common elements of international strategies were international student recruitment and purposeful engagement in institutional partnerships, with $94 \%$ and $81 \%$ of institutions reporting them as priorities, respectively. International student recruitment is an emblematic activity of internationalization in other Anglophone countries (Buckner, 2019) and is clearly a core element of institutional plans for internationalization. The importance of partnerships to Canadian institutions was also consistent throughout the various international strategies. This is no surprise, as many of the other activities accounted for in this analysis, such as study abroad or research collaborations, often occur within the context of bilateral or multilateral institutional partnerships. Some institutional strategies also set out priority countries or regions for partnerships and engagement; the most commonly mentioned regions were Asia, Europe, and Africa.

Of the 17 activities we tracked, a handful were rarely mentioned as priorities, namely online or distance learn- ing and cross-border education. For example, despite growing interest in the carbon footprint of international education (Shields, 2019) and the transformation in digital learning technologies over the past two decades, the use of online or distance learning was largely absent from the international strategies of Canadian institutions. In the context of COVID-19, interest in this activity will likely grow significantly, and we expect future institutional plans for internationalization will place much more emphasis on this activity. Another emblematic activity of international education is the branch campus, a type of cross-border delivery (Knight, 2013). However, cross-border activities were identified as a priority in only four (13\%) strategy documents. For those institutions with an overseas campus, cross-border delivery tends to be an international priority for them; however, only a few Canadian institutions have overseas operations. Lastly, the teaching of languages other than English was notably absent, appearing in only $16 \%$ of institutional strategies. The prevalence (or dominance) of the English language in the internationalization of higher education is well noted in the literature, including the limited need for Anglophone countries to engage internationally in languages other than English (Altbach, 2013). That said, it is possible that French-speaking Canadian colleges and universities identify French as an institutional priority, but we did not analyse strategies from these institutions.

Despite these commonalities, we did find support for the idea that internationalization strategies are being tailored to their institutions' specific mandates. In particular, we noticed clear differences between the priorities of universities and those of colleges, suggesting activities, and not only language, are tailored to institutions' mandates. Given their different roles in the production and dissemination of research, universities emphasized research collaboration as a core activity. Of the 23 universities included in the study, 12 are members of the U15 Group of Canadian Research Universities, and of these, $100 \%$ included research as a priority for international engagement. For example, the University of Calgary characterizes that emphasis thusly:

Being an internationalized university is not just about the proportion of international students or staff or the number of students who study abroad but rather about the extent to which internationalization enters the very fabric of our research and educational enterprise. (Appendix, University of Calgary, 2013, p. 8) 
Table 2

Priority Activities Identified in Canadian Internationalization Strategies

\begin{tabular}{lccc}
\hline \multicolumn{1}{c}{ Variable } & $\begin{array}{c}\text { Colleges } \\
(N=9)\end{array}$ & $\begin{array}{c}\text { Universities } \\
(N=23)\end{array}$ & $\begin{array}{c}\text { Total } \\
(N=32)\end{array}$ \\
\hline Student Outbound Mobility & $89 \%$ & $100 \%$ & $97 \%$ \\
Recruit International Students & $89 \%$ & $96 \%$ & $94 \%$ \\
Develop Partnerships & $89 \%$ & $78 \%$ & $81 \%$ \\
Support Research & $44 \%$ & $87 \%$ & $75 \%$ \\
Student Services & $78 \%$ & $74 \%$ & $75 \%$ \\
Curricular Reform & $67 \%$ & $61 \%$ & $63 \%$ \\
Support Faculty and Staff Mobility & $78 \%$ & $48 \%$ & $56 \%$ \\
Develop New Academic Programs & $67 \%$ & $39 \%$ & $47 \%$ \\
International Development or Capacity Building Projects & $44 \%$ & $48 \%$ & $47 \%$ \\
Alumni Relations & $11 \%$ & $39 \%$ & $31 \%$ \\
Language Teaching - English & $22 \%$ & $30 \%$ & $28 \%$ \\
Promotional Activities / Branding / Marketing On & $33 \%$ & $26 \%$ & $28 \%$ \\
Campus Extracurricular Activities & $33 \%$ & $22 \%$ & $25 \%$ \\
Provide Scholarships & $11 \%$ & $26 \%$ & $22 \%$ \\
Language Teaching - Not English & $0 \%$ & $22 \%$ & $16 \%$ \\
Cross-Border Delivery or Branch Campus & $22 \%$ & $9 \%$ & $13 \%$ \\
Online or Distance Education & $0 \%$ & $0 \%$ & $0 \%$ \\
\hline
\end{tabular}

Canadian colleges, on the other hand, showed much higher interest in developing new academic programs as a part of their international strategies $67 \%$, versus $39 \%$ for universities). For example, the strategy from Douglas College in Vancouver includes recommendations such as ensuring their "program development includes international market analysis" and the "curriculum includes a global aspect in each program" (Appendix, Douglas College, 2012, p. 1). This focus on developing new programs appears to be in line with colleges' mandate to teach applied skills. Colleges also have a reputation as being more flexible organizations than universities, so it may be easier for them to respond to changing student demands through the creation of new programs (Clark et al., 2009).

\section{Combining Strategic Benefits and Symbolic Commitments}

We then explored dominant discourses and rationales for internationalization, and whether these varied across institutions. While we conceptually distinguished between strategic benefits and symbolic commitments, we found that in fact, most activities are imbued with both symbolic and strategic rationales, often in the same sentence. In terms of strategic benefits, most internationalization strategies link internationalization to institutional reputation, prestige, and revenue. In terms of symbolic commitments, internationalization is linked to diversity, awareness, and abstract notions of quality. In contrast to the numerous references to both strategic and symbolic 
discourses, ideas associated with an anti-oppressive frame are nearly absent. To further investigate this absence, we conducted targeted searches of key words associated with the anti-oppressive framework, including equity and humility. We found that only five strategies mentioned the words "equality" or "equity" and only two mentioned the idea of humility.

In the section below, we focus on how strategies frame the four most commonly cited priority activities: international students, research, partnerships, and outbound student mobility. For each, we show strategic and symbolic discourses are often intertwined, and pull out representative quotes to illustrate this process.

\section{Recruiting International Students for Revenue, Diversity, and Quality}

Internationalization strategies devote significant attention to how many international students they intend to recruit and often from where, by identifying key markets for recruitment. This often includes explicit numerical enrollment targets. Despite the fact that actors throughout Canadian higher education recognize that international students are a major source of revenue, institutions actually tend to downplay purely financial considerations and instead draw on a wide range of other rationales. For example, international students are framed as a solution to the issue of declining populations in provinces facing demographic shifts. Mount Allison University, which is located in Sackville, New Brunswick, offers a good example of how universities in the Maritime provinces justify international student recruitment as a solution to local issues, in this case, demographic decline. Its strategy states: "Maritime universities face an additional imperative around international student recruitment. International students help to offset a declining demographic of university-aged students across Canada, but particularly in New Brunswick, Nova Scotia, and Prince Edward Island" (Appendix, Mount Allison, 2016, p. 6). Other institutions list numerous reasons for how international students benefit the institution. For example, Ryerson University, located in downtown Toronto, simultaneously discusses international students in terms of diversity, quality, rankings and revenue:

The presence of international students in our classrooms adds to a diversity of perspectives and expe- riences that enriches the learning experience for all. An institution's international student enrolment also reflects on the quality of the university-a number of the better-known university ranking methodologies use the number of international students as a metric of quality. While revenue is another motivation for seeking to increase the number of international students on campus, it should not be the focus of our efforts. (Appendix, Ryerson University, 2017, p. 18)

The quote from Ryerson shows how revenue is acknowledged, but other rationales, namely diversity of perspectives and quality, are stated first, suggesting they are the more legitimate and substantive reasons for recruiting international students. At the same time, the strategy also explicitly recognizes the fact that an institution's international student body is used to calculate its global ranking.

Fleming College also combines a variety of rationales for recruiting international students, including what they call "direct economic benefits," which presumably means added revenue to the institution and local community, as well as the benefits for the college's academic and social environment:

International students should be valued and recognized for all of their contributions, including enriching institutional life and the educational experiences of all students; providing direct economic and social benefits to local communities beyond the institution; and creating opportunities for long-lasting professional partnerships and relationships that can be of national, international and global benefit. (Appendix, Fleming College 2015, p. 3)

Although revenue generation is a widely recognized rationale for recruiting international students to Canada (GAC, 2019), we find that in official outward-facing strategy documents, institutions are rarely so explicit about their motivations. Rather, they talk about economic benefits in more abstract terms and emphasize symbolic commitments to diversity.

\section{Supporting Research for Funding and Excellence}

Research has long been a central mandate of Canadian universities. In response to calls to internationalize, 
institutions are increasingly formalizing international research collaborations. Two representative quotes of how research is portrayed in internationalization strategies come from Dalhousie and Memorial:

Research cooperation with international colleagues raises the level of research impact and provides a broader range of sources from which research funding might be accessed. The result in both cases leads to world-class contributions to global issues and an elevated institutional reputation. (Appendix, Dalhousie University, 2017, p. 7)

Although international ranking systems are hotly contested, their role in reinforcing a university's international reputation and, in turn, generating a widely-held perception of quality cannot be ignored. Enhancing reputation through excellence in research and teaching is important to a realizable internationalization strategy. (Appendix, Memorial University, 2014, p. 15)

Strategically, as the quote from Dalhousie shows, international research cooperation is framed as one way that universities can access international sources of funding. At the same time, international research cooperation is associated with increased faculty research output and thereby, framed as a means to improving an institution's ranking and global reputation. For example, Dalhousie's strategy specifically states that research will result in "elevated institutional reputation," while Memorial's strategy acknowledges that the merits of rankings are debated, it also states that they nonetheless play a role in "reinforcing a university's international reputation," and are linked to perceptions of overall quality.

Symbolically, we found that international research cooperation is often tied to ideas of excellence and impact. However, the university's research mandate is rarely framed in terms of advancing theoretical or abstract knowledge-instead, it is more often framed as solving important global challenges. As with other domains, the strategic and symbolic are coupled. For example, the quote from Dalhousie above explicitly mentions "contributions to global issues" and "elevated institutional reputation" as dual justifications for supporting research cooperation.

\section{Mutually Beneficial Partnerships}

As mentioned in the analysis of priority activities, establishing international partnerships is one of the most common priority activities for colleges and universities alike. These partnerships are framed in strategy documents as one way to enhance reputation nationally and internationally. For example, Dalhousie makes its reputational goals explicit stating that "partnerships should enhance the reputation of Dalhousie University and raise its profile, both on the national and international scenes" (Appendix, Dalhousie University, 2017, p. 13).

However, strategies also emphasize the idea that partnerships must be beneficial in order to be worth the time and resources that go into them. For example, the University of Ottawa says explicitly that because partnerships require substantial investment, they should map onto other initiatives and priorities. The strategy states: "Because international activities and partnerships maintained by the University represent a significant investment in time and resources, there is a need to move towards a regional/country strategy and cross-reference initiatives within identified geographic areas against academic and research priorities" (Appendix, University of Ottawa 2017, p. 33). Similarly, Durham College states that: "International projects and partnerships have a valuable impact on DC's internationalization efforts by building our institutional capacity to provide employees with international experiences while delivering quality programming through diverse and innovative collaborations" (Appendix, Durham College 2017, p. 9). Even though partnerships are framed as primarily strategic in these quotes, they are also linked to the overall quality of the institution and occasionally, to improving the intercultural awareness of students. For example, Durham College mentions the role that partnerships play in improving the quality of their programs.

\section{Outbound Student Mobility}

Outbound student mobility was one of the most commonly identified priorities throughout all strategies. In the context of concern for the low numbers of Canadian outbound students, strategies tend to emphasize the importance of enhancing awareness of outbound mobility and increasing the number of outbound students, while also connecting it to the idea of developing skills and competencies for a global labour market. For example, 
Durham College's strategy cites statistics on very low study abroad participation in Canada, while also stating that study abroad ensures that: "DC students will increasingly have the opportunity to apply and refine their skills internationally through international exchanges, work-integrated learning, short-term study abroad and field schools" (Appendix, Durham College, 2017, p. 8).

Similarly, at the University of Regina, outbound mobility is framed as an increasing necessity given an increasingly globalized and competitive labour market:

It is our responsibility as a University to provide our students with a Global Education, that gives them the skills and experience to enter a highly diverse and competitive job market. Such an education enhances the academic experiences of our students, by exposing them to alternative cultures and experiences that provide "a vibrant, challenging and stimulating learning environment." (Appendix, University of Regina, 2016, p. 5)

As these quotes show, supporting outbound mobility is being tied to students' labour market outcomes, more so than their understanding of other peoples and places. However, in a few examples, some intuitions do mention the connection between cultural understanding and outbound mobility. For example, the University of Saskatchewan views education abroad as a way to enable students "to experience new places, cultures, languages and traditions" (Appendix, University of Saskatchewan, n.d., p. 2). Interestingly, this explicit connection to understanding cultures is relatively rare in the strategy documents we analyze.

\section{Localizing Symbolic Justifications}

In contrast to priority activities and rationales for internationalization, which were largely similar across institutions, we found that the ways institutions discussed their local context, namely their province or city, was very specific. Discussions of internationalization reflected their specific context, including its particular geographic location, the nature of the local economy, and the demographics of the local community. Institutions in smaller cities and those with provincial mandates stress the role they play in serving their local community. For example, Memorial University specifically mentions that they have "special obligation" and are "a gateway to the world" for the people of Newfoundland and Labrador (Appendix, Memorial University, 2014, p. 3). Similarly, Nova Scotia Community College specifically mentions that their internationalization approach "helps address provincial goals of increased global competitiveness and fostering welcoming communities for immigrants" (Appendix, Nova Scotia Community College, 2013, p. 1).

Meanwhile, campuses in bigger cities are more likely to frame the university and city as benefiting each other. For example, the University of Toronto specifically mentions that they aim to "leverage the urban location more fully, for the mutual benefit of the university and the city" (Appendix, University of Toronto, 2015, p. 1). Another example is Simon Fraser University, which identifies itself as a "gateway to Asia for Canada" because of its "diaspora communities" from Asian countries (Appendix, Simon Fraser, 2013, p. 28), but also stresses it provides opportunities for local communities to engage internationally. In addition, University of Calgary says they are located in a city with "the second concentration of head offices in the nation," and that they prepare graduates that meet the need of the city of Calgary as a "global energy and financial hub" (Appendix, University of Calgary, 2013, p. 3). Ryerson University, in Toronto, mentions that their internationalization activities recognize "the diversity of knowledges, cultures and perspectives present within our own city" (Appendix, University of Ryerson, 2017, p. 11). These examples are among many that showcase universities' mutual relationships with their urban community. We interpret these differences as examples of how internationalization strategies are localizing abstracted benefits to their particular locations, stressing their strengths and particular mandates. They lend support for the idea that institutions are localizing their discussions of internationalization and its benefits. Yet, as we note above, these localizations did not seem to translate into distinctive activities or approaches.

\section{Discussion and Conclusion}

Through quantitative content analysis and qualitative coding of 32 internationalization strategies, we examine how internationalization is framed in the official documents of Canadian higher education institutions. An overarching finding is that institutions are combining both symbolic commitments to educating for a diverse world with instrumental justifications by mapping inter- 
nationalization onto research productivity, reputation, and revenue. We argue that contrary to the assumption that strategic and symbolic justifications are distinct or competing, in practice, university administrators are drawing on both simultaneously. Among the most commonly mentioned strategic benefits were revenue, reputation and rankings. Meanwhile, commitments to diversity and intercultural awareness were among the most common symbolic justifications. The dual justifications, strategic and symbolic, point to the complexity of demands facing higher education institutions: they are both economic actors that operate with limited resources and fiscal constraints, and socio-cultural actors that have embraced changing mandates, including commitments to educating for diversity and solving social issues locally and globally. We argue that by combining rationales, leaders are able to imbue the same activities with multiple meanings that may resonate with diverse stakeholders.

We also found support for the idea that leaders, in designing their internationalization strategies, are "localizing" their strategies to their institutions' mandates as well as the particular concerns of their local communities and Canadian society more broadly. For example, prioritizing internationalization activities is framed as an effective solution to various local issues such as declining provincial funding or demographic shifts in the Maritimes. Being strategic also means prioritizing certain geographic areas that best serve institutional interests given limited time and resources. However, despite the clear evidence that strategy documents are being localized to particular geographic locations, by referencing local concerns, strengths, or institutional mandates, this localization does not seem to translate into distinctive approaches or models. Instead, we argue that localization is most likely being used to garner acceptance among diverse stakeholders, without necessarily resulting in substantial innovations in practice or requiring deviations from an existing, legitimated professional model.

Importantly, we also find that many important ideas are noticeably absent from our sample of existing strategies, namely those we classify as anti-oppressive. For example, even while colleges and universities in Canada face calls to decolonize and indigenize not only their student bodies, but also their knowledge bases, internationalization is rarely linked in these documents to these parallel calls to decolonize or indigenize the academy or to deconstruct the Eurocentrism within global higher education (Buckner \& Stein, 2020; Stein, 2017). Institutions seem to be more comfortable with couching discussions of internationalization in discourses for diversity and quality, than equity or equality. Similarly, internationalization is rarely linked to global issues such as climate crisis, sustainability, or broader geopolitical issues affecting Canadian higher education. This finding raises questions about how we might advance conversations about the role of values in internationalization, including whether institutions should be explicit about their values and how they might enact these values in their institutional strategies and practices.

\section{Acknowledgements}

An earlier version of this article was presented at the Shaping Sustainable Futures for Internationalization in Higher Education Conference in 2019. This research was made possible with funding from a SSHRC Institutional Grant. We would like to thank the following students for their generous research assistance: Taiya Brown, Cassidy Gong, Zahra Jafarova, Eun (Phoebe) Kang, Freeda Khan, Punita Lumb, Sarah Morales, Hooman Razavi, and Yinjia Zhang.

\section{References}

Altbach, P. G. (2013). The imperial tongue: English as the dominating academic language. In P. G. Altbach (Ed.), The international imperative in higher education (pp. 1-6). Brill | Sense.

Altbach, P. G., \& Knight, J. (2007). The internationalization of higher education: Motivations and realities. Journal of Studies in International Education, 11(3-4), 290-305. https://doi. org/10.1177/1028315307303542

Anderson, T. (2015). Seeking internationalization: The state of Canadian higher education. Canadian Journal of Higher Education, 45(4), 166-187. https://journals.sfu.ca/cjhe/index.php/cjhe/article/view/184690

Association of Canadian Community Colleges (ACCC). (2010). Internationalizing Canadian colleges and institutes: The first national report on international education and mobility. https://www.collegesinstitutes. 
ca/file/internationalizing-canadian-colleges-and-institutes-the-first-national-report-on-international-education-and-mobility/?wpdmdl=10900

Association of Universities and Colleges of Canada. (2014). Canada's universities in the world: AUCC internationalisation survey. https://www. univcan. ca/wp-content/uploads/2015/07/internationalization-survey-2014.pdf

Beck, K. (2012). Globalization/s: Reproduction and resistance in the internationalization of higher education. Canadian Journal of Education, 35(3), 133-148. https://www.jstor.org/stable/canajeducrevucan.35.3.133\#metadata info tab contents

Boxenbaum, E. (2006). Lost in translation: The making of Danish diversity management. American Behavioral Scientist, 49(7), 939-948. https://doi. org/10.1177/0002764205285173

Buckner, E. (2017). The changing discourse on higher education and the nation-state, 1960-2010. Higher Education, 74(3), 473-489. https://doi.org/10.1007/ s10734-016-0056-2

Buckner, E. (2019). The internationalization of higher education: National interpretations of a global model. Comparative Education Review, 63(3), 315-336. https://www.journals. uchicago.edu/doi/ pdfplus/10.1086/703794

Buckner, E., \& Stein, S. (2020). What counts as internationalization? Deconstructing the internationalization imperative. Journal of Studies in International Education, 24(2), 151-166. https://doi. org/10.1177/1028315319829878

Canadian Bureau of International Education (CBIE). (2016). Canadian students abroad [Infographic]. https://cbie.ca/wp-content/uploads/2018/04/Infographic-abroad-EN.pdf

Charmaz, K. (2006). Coding in grounded theory practice. In K. Charmaz (Ed.), Constructing grounded theory: A practical guide through qualitative analysis (pp. 42-71). Sage.

Chen, L. H. (2006). Attracting East Asian students to Canadian graduate schools. Canadian Journal of Higher Education, 36(2), 77-105. https://journals.sfu.cal cjhe/index.php/cjhe/article/view/183540/183485
Childress, L. (2009). Internationalization plans for higher education institutions. Journal of Studies in International Education, 13(3), 289-309. https://doi. org/10.1177/1028315308329804

Clark, I., Moran, D., Skolnik, M. L., \& Trick, D. (2009). Academic transformation: The forces shaping higher education in Ontario. McGill-Queen's University Press.

Dedoose Version 8.0.35, web application for managing, analyzing, and presenting qualitative and mixed method research data. (2018). SocioCultural Research Consultants, LLC. www.dedoose.com

de Wit, H., Hunter, F., Egron-Polak, E., \& Howard, L. (2015). Internationalisation of Higher Education. European Parliament. https://www.europarl.europa. eu/RegData/etudes/STUD/2015/540370/IPOL STU(2015)540370 EN.pdf

El-Assal, K. (2020). 642,000 international students: Canada now ranks 3rd globally in foreign student attraction. CIC News. https://www.cicnews. com/2020/02/642000-international-students-canada-now-ranks-3rd-globally-in-foreign-student-attraction-0213763.html

Enders, J. (2004). Higher education, internationalisation, and the nation-state: Recent developments and challenges to governance theory. Higher Education, 47(3), 361-382. https://doi.org/10.1023/ B:HIGH.0000016461.98676.30

Foreign Affairs, Trade and Development Canada (FATDC). (2014). Canada's international education strategy: Harnessing our knowledge advantage to drive innovation and prosperity. https://www.international. gc.ca/education/assets/pdfs/overview-apercu-eng. pdf

Garson, K. (2016). Reframing internationalization. The Canadian Journal of Higher Education, 46(2), 19-39. https://journals.sfu.ca/cjhe/index.php/cjhe/ article/view/185272

Global Affairs Canada (GAC). (2019). Building on success: International education strategy 2019-2024. Government of Canada. https://www. international.gc.ca/education/assets/pdfs/ies-sei/ Building-on-Success-International-Education-Strate- 


\section{gy-2019-2024.pdf}

Grantham, K. (2018). Assessing international student mobility in Canadian university strategic plans: Instrumentalist versus transformational approaches in higher education. Journal of Global Citizenship \& Equity Education, 6(1), 1-21. http://journals.sfu.cal igcee/index.php/igcee/article/view/176

Guo, Y., \& Guo, S. (2017). Internationalization of Canadian higher education: Discrepancies between policies and international student experiences. Studies in Higher Education, 42(5), 851-868. https://doi.org/ 10.1080/03075079.2017.1293874

Institute of International Education. (2017). 2017 Project Atlas infographics. https://www.iie.org/ Research-and-Insights/Project-Atlas/Explore-Data/ Infographics/2017-Project-Atlas-Infographics

Kenyon, K., Frohard-Dourlent, H., \& Roth, W. D. (2012). Falling between the cracks: Ambiguities of international student status in Canada. Canadian Journal of Higher Education, 42(1), 1-24. https://journals. sfu.ca/cihe/index.php/cijhe/article/view/1991

Khoo, S. (2011) Ethical globalisation or privileged internationalisation? Exploring global citizenship and internationalisation in Irish and Canadian universities. Globalisation, Societies and Education, 9(3-4), 337-353. https://doi.org/10.1080/14767724.2011.6 $\underline{05320}$

Knight, J. (2004). Internationalization remodeled: Definition, approaches, and rationales. Journal of Studies in International Education, 8(1), 5-31. https://doi. org/10.1177/1028315303260832

Knight, J. (2013). The changing landscape of higher education internationalisation-for better or worse? Perspectives: Policy and Practice in Higher Education, 17(3), 84-90. https://doi.org/10.1080/13603108 .2012 .753957

Marginson, S., \& van der Wende, M. (2007). “To rank or to be ranked: The impact of global rankings in higher education." Journal of Studies in International Education, 11(3-4), 306-329. https://doi. org/10.1177/1028315307303544

Nerad, M. (2010). Globalization and the internationalization of graduate education: A macro and micro view.
Canadian Journal of Higher Education, 40(1), 1-12. https://journals.sfu.ca/cihe/index.php/cihe/article/ view/1566

Pusser, B., \& Marginson, S. (2013). University rankings in critical perspective. The Journal of Higher Education, 84(4), 544-568. https://doi.org/10.1080/002215 46.2013.11777301

Sahlin, K., \& Wedlin, L. (2008). Circulating ideas: Imitation, translation and editing. In R. Greenwood, C. Oliver, K. Sahlin, \& R. Suddaby (Eds.), The SAGE Handbook of Organizational Institutionalism (pp. 218-242). Sage.

Schoorinan, D. (1999). The pedagogical implications of diverse conceptualizations of internationalization: A US based case study. Journal of Studies in International Education, 3(2), 19-46. https://doi.org/10.1177 \%2F102831539900300203

Seeber, M., Cattaneo, M., Huisman, J., \& Paleari, S. (2016). Why do higher education institutions internationalize? An investigation of the multilevel determinants of internationalization rationales. Higher Education, 72(5), 685-702. https://link.springer.com/ article/10.1007/s10734-015-9971-x

Seeber, M., Meoli, M., \& Cattaneo, M. (2020). How do European higher education institutions internationalize? Studies in Higher Education, 45(1), 145-162. https://doi.org/10.1080/03075079.2018.1541449

Shields, R. (2019). The sustainability of international higher education: Student mobility and global climate change. The Journal of Cleaner Production, 217(2019), 594-602. https://doi.org/10.1016/j. jclepro.2019.01.291

Soliman, S., Anchor, J., \& Taylor, D. (2018). The international strategies of universities: deliberate or emergent? Studies in Higher Education, 44(8), 1413-1424. https://doi.org/10.1080/03075079.2018 .1445985

Statistics Canada. (2019a). Table 37-10-0018-01. Postsecondary enrolments, by registration status, institution type, status of student in Canada and gender. https://doi.org/10.25318/3710001801-eng

Statistics Canada. (2019b). Table 37-10-0045-01. Canadian and international tuition fees by level of 
study. https://www150.statcan.gc.ca/t1/tbl1/en/tv.action?pid=3710004501

Stein, S. (2015). Mapping global citizenship. Journal of College and Character, 16(4), 242-252. https://doi. org/10.1080/2194587X.2015.1091361

Stein, S. (2017). The persistent challenges of addressing epistemic dominance in higher education: Considering the case of curriculum internationalization. Comparative Education Review, 61(1), 25-50. http://doi.org/0010-4086/2017/61S1-003

Stein, S. (2019). Critical internationalization studies at an impasse: Making space for complexity, uncertainty, and complicity in a time of global challenges. Studies in Higher Education. http://doi.org/10.1080/ 03075079.2019.1704722

Stein, S., Andreotti, V., \& Suša, R. (2019). Pluralizing frameworks for global ethics in the internationalization of higher education in Canada. Canadian Journal of Higher Education/Revue canadienne d'enseignement supérieur, 49(1), 22-46. https:/l journals.sfu.ca/cjhe/index.php/cjhe/article/ view/188244/186329

Stein, S., \& Andreotti, V. (2016). Cash, competition, or charity: International students and the global imaginary. Higher Education, 72(2), 225-239. https://doi. org/10.1007/s10734-015-9949-8

Stensaker, B., Lee, J. J., Rhoades, G., Ghosh, S., Castiello-Gutiérrez, S., Vance, H., Çalıkoğlu, A., Kramer, V., Liu, S., Marei, M. S., O'Toole, L., Pavlyutkin, I., \& Peel, C. (2019). Stratified university strategies: The shaping of institutional legitimacy in a global perspective. The Journal of Higher Education, 90(4), 539-562. https://doi.org/10.1080/00221546.2018.1 $\underline{513306}$

Taylor, J. (2004). Toward a strategy for internationalisation: Lessons and practice from four universities. Journal of Studies in International Education, 8(2), 149-171. https://doi. org/10.1177\%2F1028315303260827

Trilokekar, R. D. (2010). International education as soft power? The contributions and challenges of Canadian foreign policy to the internationalization of higher education. Higher Education, 59(2), 131-147. https://www.jstor.org/stable/25622172

Waldow, F. (2018). Commentary to part III: Why is "Being International" so attractive? "Being International" as a source of legitimacy and distinction. In C. Maxwell, U. Deppe, H.-H Krüger, \& W. Helsper (Eds.), Elite education and internationalisation: From the early years to higher education (pp. 247-253).

Palgrave Macmillan.

\section{Contact Information}

Elizabeth Buckner

elizabeth.buckner@utoronto.ca 


\section{APPENDIX: List of Institutions}

\begin{tabular}{|c|c|c|c|}
\hline Institution & Title of Document & Date Published & Document URL \\
\hline Algonquin College & International Strategy & 2018 & $\begin{array}{l}\text { https://www.algonquincollege.com/ } \\
\text { international/files/2018/08/Algonquin-Col- } \\
\text { lege-International-Strategy-v4_22Aug18. } \\
\text { pdf }\end{array}$ \\
\hline Dalhousie University & $\begin{array}{l}\text { Dalhousie University's } \\
\text { International Strategy }\end{array}$ & 2017 & $\begin{array}{l}\text { https://cdn.dal.ca/content/dam/dalhousie/ } \\
\text { pdf/dept/international-relations/DALHOU- } \\
\text { SIE\%20INTERNATIONAL\%20STRATE- } \\
\text { GY\%202017-2020-June-2018.pdf }\end{array}$ \\
\hline Douglas College & $\begin{array}{l}\text { Internationalization } \\
\text { Implementation Plan }\end{array}$ & 2012 & No longer available \\
\hline Durham College & $\begin{array}{l}\text { Internationalization and } \\
\text { Global Engagement Plan }\end{array}$ & 2017 & $\begin{array}{l}\text { https://www.durhamcollege.ca/wp-con- } \\
\text { tent/uploads/dc-internationaliza- } \\
\text { tion-and-global-engagement-plan-2017-fi- } \\
\text { nal.pdf }\end{array}$ \\
\hline Fleming College & Internationalization Plan & 2015 & $\begin{array}{l}\text { https://flemingcollege.ca/PDF/Internation- } \\
\text { alization-Plan-2015-2018.pdf }\end{array}$ \\
\hline Humber College & $\begin{array}{l}\text { Internationalization } \\
\text { Strategy 2018-2023 }\end{array}$ & 2018 & $\begin{array}{l}\text { https://international.humber.ca/blog/ } \\
\text { assets/files/Humber-Internationaliza- } \\
\text { tion-Strategy-2018-2023(1).pdf }\end{array}$ \\
\hline MacEwan University & $\begin{array}{l}\text { MacEwan University's } \\
\text { Strategic } \\
\text { Internationalization Plan }\end{array}$ & 2016 & $\begin{array}{l}\text { http://www.macewan.ca/contribute/ } \\
\text { groups/public/documents/document/stra- } \\
\text { tegic_intlz_plan.pdf }\end{array}$ \\
\hline McGill University & $\begin{array}{l}\text { International Strategy } \\
\text { and Framework }\end{array}$ & n.d. & $\begin{array}{l}\text { https://www.mcgill.ca/science/files/sci- } \\
\text { ence/international_framework_and_geo- } \\
\text { graphic_priorities140311.pdf }\end{array}$ \\
\hline McMaster University & $\begin{array}{l}\text { The McMaster Model for } \\
\text { Global Engagement: A } \\
\text { Strategy Document }\end{array}$ & 2017 & $\begin{array}{l}\text { https://global.mcmaster.ca/app/up- } \\
\text { loads/2018/10/Global-Engagement-Strat- } \\
\text { egy-2017.pdf }\end{array}$ \\
\hline Memorial University & $\begin{array}{l}\text { Strategic } \\
\text { Internationalization Plan } \\
2020 \text { (Draft) }\end{array}$ & 2014 & $\begin{array}{l}\text { http://www.mun.ca/research/SIP_PDF_ } \\
\text { for_web_Sept_2014.pdf }\end{array}$ \\
\hline Mount Allison University & $\begin{array}{l}\text { Mount Allison's } \\
\text { Internationalization } \\
\text { Strategy (Draft) }\end{array}$ & 2016 & $\begin{array}{l}\text { https://www.mta.ca/uploadedFiles/Com- } \\
\text { munity/Governance_and_admin/VP_In- } \\
\text { ternational_and_Student_Affairs/Stu- } \\
\text { dent_Affairs_Strategic_Plan/DRAFT\%20 } \\
\text { Mount\%20Allison's\%20Strategic\%20 } \\
\text { Internationalization\%20Plan\%2016-11- } \\
\text { 01.pdf }\end{array}$ \\
\hline
\end{tabular}




\begin{tabular}{|c|c|c|c|}
\hline Institution & Title of Document & Date Published & Document URL \\
\hline $\begin{array}{l}\text { Nova Scotia } \\
\text { Community College }\end{array}$ & $\begin{array}{l}\text { NSCC International } \\
\text { Strategy }\end{array}$ & 2013 & $\begin{array}{l}\text { http://international.nscc.ca/wp-content/ } \\
\text { uploads/2013/08/NSCC-Int-strategy-one- } \\
\text { pager-20131.pdf }\end{array}$ \\
\hline Queen's University & $\begin{array}{l}\text { Comprehensive } \\
\text { International Plan }\end{array}$ & 2015 & $\begin{array}{l}\text { https://www.queensu.ca/sites/default/files/ } \\
\text { assets/pages/strategicframework/QU- } \\
\text { 2015-Comp-International-Plan-acc.pdf }\end{array}$ \\
\hline Red Deer College & $\begin{array}{l}\text { Framework for } \\
\text { Internationalization at } \\
\text { Red Deer College }\end{array}$ & 2014 & No longer available \\
\hline Ryerson University & $\begin{array}{l}\text { Priorities for } \\
\text { Internationalization at } \\
\text { Ryerson }\end{array}$ & 2017 & $\begin{array}{l}\text { https://www.ryerson.ca/content/dam/ri/ } \\
\text { download/Internationalization_Discus- } \\
\text { sion.pdf }\end{array}$ \\
\hline Selkirk College & $\begin{array}{l}\text { Internationalization } \\
\text { Strategic Plan }\end{array}$ & 2017 & $\begin{array}{l}\text { https://selkirk.ca/sites/default/files/Stra- } \\
\text { tegic\%20Plan/Internationalization\%20 } \\
\text { Stratiegic\%20Plan\%202017\%2004.pdf }\end{array}$ \\
\hline Sheridan College & $\begin{array}{l}\text { The International Centre } \\
\text { Plan }\end{array}$ & 2018 & $\begin{array}{l}\text { https://www.sheridancollege.ca/-/ } \\
\text { media/files/www/about/adminis- } \\
\text { tration-and-governance/priorities/ } \\
\text { the-international-centre-plan.ashx- } \\
\text { ?la=en\&hash=FD2DAFBC5AA13C8A- } \\
\text { 728FAC8AD5B69AA22BF0AF2D }\end{array}$ \\
\hline $\begin{array}{l}\text { Simon Fraser } \\
\text { University }\end{array}$ & $\begin{array}{l}\text { International } \\
\text { Engagement Strategy }\end{array}$ & 2013 & $\begin{array}{l}\text { http://www.sfu.ca/content/dam/sfu/interna- } \\
\text { tional/documents/Int\%20Engagement\%20 } \\
\text { Strategy.pdf }\end{array}$ \\
\hline $\begin{array}{l}\text { University of British } \\
\text { Columbia }\end{array}$ & $\begin{array}{l}\text { International Strategy - } \\
\text { Draft Framework }\end{array}$ & 2020 & $\begin{array}{l}\text { https://academic.ubc.ca/sites/vpa.ubc. } \\
\text { ca/files/documents/UBC-Global-Engage- } \\
\text { ment-Strategy-IN-SERVICE-Draft-19- } \\
\text { June-2020.pdf }\end{array}$ \\
\hline University of Calgary & $\begin{array}{l}\text { Becoming a Global } \\
\text { Intellectual Hub }\end{array}$ & 2013 & $\begin{array}{l}\text { http://umanitoba.ca/admin/mco/media/ } \\
\text { PRE-00-018-StrategicPlan-Booklet_Web- } \\
\text { Pdf_FNL_optim.pdf }\end{array}$ \\
\hline University of Manitoba & $\begin{array}{l}\text { International Strategy: } \\
\text { Manitoba's Gateway to } \\
\text { the World }\end{array}$ & 2014 & $\begin{array}{l}\text { http://umanitoba.ca/admin/mco/media/ } \\
\text { PRE-00-018-StrategicPlan-Booklet_Web- } \\
\text { Pdf_FNL_optim.pdf }\end{array}$ \\
\hline $\begin{array}{l}\text { University of Ontario } \\
\text { Institute of Technology }\end{array}$ & International Plan & 2015 & $\begin{array}{l}\text { https://shared.ontariotechu.ca/shared/ } \\
\text { department/international/international-of- } \\
\text { fice-files-and-photos-15-and-16/files- } \\
\text { forms/uoit-international-plan-2015---2020. } \\
\text { pdf }\end{array}$ \\
\hline
\end{tabular}




\begin{tabular}{|c|c|c|c|}
\hline Institution & Title of Document & Date Published & Document URL \\
\hline University of Ottawa & $\begin{array}{l}\text { Internationalization } \\
\text { Strategy }\end{array}$ & 2017 & $\begin{array}{l}\text { https://www.uottawa.ca/president/ } \\
\text { sites/www.uottawa.ca.president/ } \\
\text { files/2017-12-04_-_full_report_final_ac- } \\
\text { cessible.pdf }\end{array}$ \\
\hline University of Regina & Internationalization Plan & 2016 & $\begin{array}{l}\text { https://www.uregina.ca/president/assets/ } \\
\text { docs/PVPA\%20docs/Deans_Council_Bul- } \\
\text { letins/Internationalization_Plan-23- } \\
\text { Feb-2016.pdf }\end{array}$ \\
\hline $\begin{array}{l}\text { University of } \\
\text { Saskatchewan }\end{array}$ & $\begin{array}{l}\text { Connecting with the } \\
\text { World: The International } \\
\text { Blueprint for Action } 2025\end{array}$ & n.d. & $\begin{array}{l}\text { https://www.usask.ca/ipa/documents/in- } \\
\text { ternational-blueprint.pdf }\end{array}$ \\
\hline $\begin{array}{l}\text { University of the Fraser } \\
\text { Valley }\end{array}$ & $\begin{array}{l}\text { Beyond Local: UFV } \\
\text { Internationalization } \\
\text { Goals, 2017-2022 }\end{array}$ & 2017 & $\begin{array}{l}\text { https://www.ufv.ca/media/assets/institu- } \\
\text { tional-research/planning/strategic-initia- } \\
\text { tives/Internationalization-Goals-UFV.pdf }\end{array}$ \\
\hline University of Toronto & $\begin{array}{l}\text { Global Engagement: } \\
\text { UofT in the World }\end{array}$ & 2015 & $\begin{array}{l}\text { https://global.utoronto.ca/wp-content/up- } \\
\text { loads/2015/08/UofT-FinalAR-2018.pdf }\end{array}$ \\
\hline University of Victoria & $\begin{array}{l}\text { Making a World of } \\
\text { Difference: International } \\
\text { Plan }\end{array}$ & 2017 & $\begin{array}{l}\text { https://www.uvic.ca/_assets/docs/interna- } \\
\text { tional-plan.pdf }\end{array}$ \\
\hline University of Waterloo & $\begin{array}{l}\text { Waterloo Bridge to 2020: } \\
\text { Internationalization }\end{array}$ & 2018 & $\begin{array}{l}\text { https://uwaterloo.ca/strategic-plan/bridge- } \\
\text { to-2020/issue-papers/internationalization }\end{array}$ \\
\hline University of Windsor & $\begin{array}{l}\text { Moving Toward Campus } \\
\text { Internationalization }\end{array}$ & 2011 & $\begin{array}{l}\text { http://web4.uwindsor.ca/international-de- } \\
\text { velopment/sites/uwindsor.ca.internation- } \\
\text { al-development/files/internationalization_- } \\
\text { report_2011-12.pdf (No longer available) }\end{array}$ \\
\hline $\begin{array}{l}\text { Vancouver Island } \\
\text { University }\end{array}$ & $\begin{array}{l}\text { Vancouver Island Univer- } \\
\text { sity International } \\
\text { Education: Strategic } \\
\text { Vision }\end{array}$ & 2017 & $\begin{array}{l}\text { https://international.viu.ca/sites/default/ } \\
\text { files/viu_international_strategicvi- } \\
\text { sion2017.pdf }\end{array}$ \\
\hline Western University & International Action Plan & 2014 & $\begin{array}{l}\text { https://international.uwo.ca/pdf/Interna- } \\
\text { tional\%20Strategy\%202014-2019.pdf }\end{array}$ \\
\hline
\end{tabular}

